\title{
COMPANY PERFORMANCE: ANALYSIS OF HARDSKILL, SOFT SKILL AND MOTIVATION at the PT. Manunggal Perkasa
}

\author{
*Gimbal Doloksaribu
}

Lecturer of Mercu BuanaUniversity, Jakarta Indonesia

\section{A R T I C L E I N F O}

\section{Article History:}

Received $12^{\text {th }}$ December, 2016

Received in revised form $16^{\text {th }}$ January, 2017

Accepted $6^{\text {th }}$ February, 2017

Published online $28^{\text {th }}$ March, 2017

\section{Key words:}

Hard Skills, Soft Skills, Motivation, Performance

\begin{abstract}
A B S T R A C T
This study aimed to analyze the Hard Skill Effect, Soft Skill and Motivation either partially or simultaneously to the Company's Performance in PT. Manunggal Perkasa. In this study using primary data and secondary data by distributing a questionnaire tool. The samples are saturated sample of 62 respondents. This data was obtained using multiple linear regression analysis, correlation analysis, $\mathrm{t}$ test, and $\mathrm{F}$ test. Results from multiple linear regression calculations to analyze the equation, that is $\mathrm{Y}=6,842+0,152 \mathrm{X} \_1+0,264 \mathrm{X} \_2+$ $0,208 X \_3$. The results of the calculation of the $t$ test, between hard skills, soft skills, and motivation against the performance values obtained on the $t$ test tValue $>t$ table, namely 2.622 and 0.011 significant after $t$ value it must find t table value $(\alpha=0.05)$ is 1,99 . Because the value $t$ Value $>t$ table namely $(2.622>1.99)$ with a significance level $<0.05$ $(0.000<0.05)$, then Ho is rejected, the conclusion that hard skills, Soft Skills and Motivation partially significant effect on performance. Results of the calculations for $21.744 \mathrm{ftest}$ obtained with a significant level of 0.000 after $\mathrm{f}$ valuevalue it must find $\mathrm{f}$ table $(\alpha=0.05)$ was 2.76 . Because the F value is greater than the Ftable $(21.744>2.76)$ with a significant level of $0.000<0.05$, it can be concluded that Ho is rejected, meaning Hard Skills, Soft Skills and Motivation jointly affect the performance.
\end{abstract}

Copyright $₫ 2017$ Gimbal Doloksaribu. This is an open access article distributed under the Creative Commons Attribution License, which permits unrestricted use, distribution, and reproduction in any medium, provided the original work is properly cited.

\section{INTRODUCTION}

\section{Background}

One of the most important factors and can determine the success or failure of an organization is its human resources. Competitive advantage (Competitive Advantage) an organization is determined by the quality of its human resources. Therefore, human resource management must be applied thoroughly and carefully within the framework of the management system that is strategic, integrated and always connected, to the purpose and the vision and mission of the organization.

Said the organization succeed if mentioned organization can underlie its activities with high creativity, knowledge, and expertise, or so-called hard skills. Hard skills can be measured by a test that has to do with the field being studied, so that the hard skills can be said to be visible or tangible. Academic and technical competence "Hard skills" more easily selected. Competence can be seen on resumes, job experience, GPA and skills mastered. As for the soft skills are usually evaluated by psychologists through psychological test and interview.

*Corresponding author: Gimbal Doloksaribu

Lecturer of Mercu BuanaUniversity, Jakarta Indonesia
Interpretation of the results of a psychological test, although it is not guaranteed $100 \%$ correct, but help the company in putting human resource competence.

Hard skills are important factors in the company, but the company's success is usually determined by its Soft skills are good. At the level of the more operational, soft skills associated with a person's skills in dealing with people (interpersonal skills), and skills in self-regulating (interpersonal both of these can affect the development of the performance to the maximum. Soft skills are considered important because many experts argue that the biggest problems in the organization of this century is a matter of attitude and behavior of employees in almost all organizations of the slowing down of motivation, poor quality in communication, teamwork weak to incompetence leads that ultimately led to cases of indiscipline and employee productivity.

Human Resources planning through mature, performance of the company already. There can be improved. This can be realized through the adjustment. Such as increased motivation is good, so that each employee can produce something that is directly related to the interests of the company. Good motivation can also support the company's success in achieving its objectives. The existence of these factors will create a high productivity level of performance so that the 
success of the company, otherwise if the rate decreased work productivity will hamper the company in achieving its goals

Motivation is important in increasing an effectiveness of the work for people who have high motivation will bend over backwards in order his job can succeed as well as possible, will establish a performance improvement company. Every company wants increased company performance. To achieve this, companies must be able to motivate all employees, in order to achieve the performance and improve company performance.

Performance is a condition that must be known and informed of certain parties to determine the level of achievement of results associated with the vision of an agency assigned to an organization and determine the positive and negative impacts of an operational policy in the capture. The company's performance is the result of a series of business processes at the expense of a variety of human and financial resources of the company.

PT. Manunggal Perkasa is a service business engaged in purchasing goods from an online store. Indoshopaholics.com has been operating since July 2011 and to date have been making purchases using Paypal, Visa, Mastercard, Gwallet of thousands Customers who give trust. Indoshopaholics can help you import needs both units as well as wholesale.

Indoshopaholics provide money back guarantee if the goods are not up. Depending on the type of service used. If using a standard service, we act as an intermediary for a buyer and a seller, buyer to use our services because they can not transact with sellers. Purchases will directly use the buyer's name and address sent to the buyer, so the responsibility is entirely in the hands of the buyer.

Work management in a company can only be run with maximum results if conducted good cooperation between the management and employees of PT. Manunggal Perkasa. One important thing that is often much less aware of is that the merits of cooperation between management and employees is highly dependent on the harmony between their personal relationships.

\section{Research purposes}

Based on the background of the problem, the purpose of this research is:

1. To analyze the effect on the performance of the company Hard Skill

2. To analyze the effect of Soft Skills on the performance of the company

3. To analyze the effect of motivation on the performance of the company

4. To analyze the effect of Hard Skills, Soft Skills and Motivation simultaneously on the performance of the company, PT. Manunggal Perkasa.

\section{LITERATURE REVIEWANDHYPOTHESES}

\section{Human Resource Management}

Human Resource Management is a process of dealing with various issues on the scope of the employee, employees, workers, managers and other workers to be able to support the activities of the organization or company to achieve its intended purpose. Section or unit that usually take care of HR is a human resources department or in English is called HR or Human Resource Department.

Human Resource Management system design also involves planning, employee, employee development, career management, performance evaluation, compensation of employees and good labor relations. Human resource management involving all decisions and management practices directly influencehuman resources. The following is the understanding of Human Resource Management (HRM) according to the experts:

Definition of Human Resource Management by M, Manullang (2004: 198), is "Human Resource Management is the art and science of procurement, development and utilization of human resources so that the company's goals can be realized in efficiency and working enthusiasm of all work".

Meanwhile, Human Resource Management by Mathis and Jackson (2006: 11) is: "An art science to carry out, among others, planning, organizing and controlling so that the effectiveness and efficiency of personnel can be increased as much as possible in achieving the goals"

Human Resource Management (HRM) by HadariNawawi (2003: 42) is "The process of utilizing human labor as humanly so physical and psychological potential possessed functioning optimally to achieve the goal of the company".

Human Resource Management by R. Wayne Mondy (2008: 15) is: "Planning, organizing, directing and monitoring dart procurement of labor, development, compensation, integration and maintenance of employment and dismissal, working to achieve organizational goals, individuals and society ".

It can be said that the Human Resource Management is a science and art or the process of acquiring, advancing, and develop and maintain a competent workforce such that corporate objectives can be achieved efficiently and there is satisfaction in self. So basically human resource management is not only about things that happen tranquility in the organization of work, but also need to reach organizational environment that influence the development of human resources within the organization. Meanwhile promote and develop human resources must continue to be done with regard to the development environment of the organization, in particular the development of science and technology in addition to environmental factors other organizations. In addition, human resource management showed an understanding that labor as a resource acquired, developed and maintained must have competence in the sense of having the ability and willingness of an appropriate and support the tasks they are responsible. Labor is wealth or assets of the organization in the form of human resources who have ideals, sense, intention different, so it should be managed by the social system approach that puts human beings as social creatures.

Based on the opinions of the above, then penults can draw the conclusion that the definition of human resource management is the science and art of how best to carry out management functions so that the management and misuse of human resources can be developed to the maximum in the world of work to achieve organizational goals. 


\section{Definitions Hard Skill}

Hard Skill here means a mastery of science, technology, and technical skills related to the field of science. Hard skills are the technical skills inherent or necessary for a particular profession. By Leslie T. Giblin (2001) Hard Skill is: "Same with loud competencies that an employee expertise and knowledge required in order to carry out the job as expected to be achieved".

Hard skills generate degrees response and implementation of competitive advantage for the better. Hard skills led to increased knowledge, skill, judgment, and the ability of employees increased. The company's goal is to develop a variety of hard skills to improve the degree, response management company will focus on efforts to identify skills that the company had.

Hard skill in position as a key entry (Thurau2004), the conceptual hard skill that offers a perfect combination of knowledge, expertise and willingness oriented on the acquisition of equipment or technology. Emphasis Hard skills are realized by constructing a better process and system services that can generate competitive advantages of the company.

Hard skills are a competitive tool is effective in achieving responsiveness. The hard skill to be one of the critical factors for customers to make decisions (Thurau, 2004). Technical knowledge which includes knowledge regarding the design and features of a product within the company. Develop it in accordance with the technology, can solve problems that occur, and to analyze the usefulness of the product or the waiter.

\section{Hard Skill Indicators}

Indicators according to Watson Wyatt hard skill in Noor Fuad (2009: 19) include: Knowledge, Skills, expertise.

\section{(a) Knowledge}

Knowledge is a mixture of experience, values, contextual informal, and the view of experts that provides a framework to evaluate and integrate new experiences and information. Owned and applied knowledge in the minds of the owner's knowledge. In the company of knowledge is often associated not only in documents or archives, but also in organizational routines. Processes, practices and norms of the company.

\section{(b) Skill}

Is the necessary capacity to carry out some of the tasks is the development of training results and experience gained.

\section{(c) Qualification}

Is one's proficiency in a science or field of competence.

\section{Soft Skill}

Soft skills are skills a person in touch with other people (interpersonal skills) and self-regulation skills (interpersonal skills) that are able to develop the maximum performance. Examples include soft skills: adaptability, communication, leadership, decision making, problem solving, conflict resolution.
Solt skill can be assessed using in-depth interviewing techniques and a thorough interview with the behavioral approach. With behavioral interview, is expected candidates not only have the hard skills but also supported by a good soft skill.

According Ramdhani (2008) soft skills often called soft skills are the skills that are used in touch and cooperate with others. Broadly speaking, these skills can be grouped into:

- Process Skills
- Social Skills
- Generic Skills

The author of the books series of self-management, Aribowo, dividing soft skills or people skills into two parts, namely:

1) Intrapersonal Skills. Intrapersonal skills is the skill to "regulate" themselves. Intrapersonal skills should be addressed first before a person begins to relate to others.

2) Interpersonal Skill. The Interpersonal skills are the skills needed someone to relate to others.

From the description above, it can be deduced hard skill is mastery of science, technology and technical skills related to the field of science. While soft skills are skills a person in touch with other people (including himself). All professions require skills (hard skills) but all profession particular need soft skills.

\section{Soft Skill Indicators}

Soft skills indicator in TjutjuYuniarsih according to Spencer (2008: 3) includes: Personality, Honesty, Nature / innate characteristic, and the concept itself.

Personality. Is the nature and behavior is typical of someone who sets it apart from others, the integration of the characteristics of structures, patterns of behavior, interests, establishments, capability and potential of a person, everything about the person as to which is known by others.

Honesty. Is when we say something in accordance with reality. Honestly could also mean the attitude we deal with a situation. Or it could be honest in saying what we think and we feel inside suit what we say in the mouth.

Motivation. What consistently thinks or desires that lead to action. What drives the behaviors that lead to and are selected on the activities or certain destinations.

Sifaf innate characteristics. Is the physical characteristics and reactions that are consistent with the situation and information.

Self concept. It is the attitudes, values, or the self-image of people like confidence (Self Confidence), the belief he would be effective in a variety of situations, is part of the concept itself.

\section{Motivation}

Motivation is a behavior that wants to achieve certain goals that tend to settle. Motivation is also a force to propel and steer the success of behavior that remain toward specific goals. Motivation can come from within oneself or from outside himself. Motivation comes from within a person 
called intrinsic motivation, and that comes from outside is extrinsic motivation.

Motivation is ability to motivate ourselves without needing the help of others. Motivating ourselves is the process of removing the factors that weaken our encouragement. A sense of helplessness eliminated being personally more confident. While the expectations raised again to build the desired confidence that what we can accomplish.

Thus, if a motivation (in this case the helplessness and hopeless) is eliminated, then the energy flow in our body can flow back, and in this paper, the author will try to discuss about the motivation and the various theories of motivation.

The notion of motivation by Wahjosumidjo (2003: 174) is "A psychological process that reflects the interaction between the attitudes, needs, perceptions, and decisions were made in a person to behave in order to meet the felt needs".

According to Samsudin (2005) give a sense of motivation "As the process of influencing or encouraging and out against an individual or group work that they want to accomplish something that has been set. Motivation can also be interpreted as an impulse (driving force) is intended as an insistence natural to satisfy and sustain life ".

Mangkunagara (2005: 61) stated motivation is "attitude (attitude) of employees in the face of the employment situation in the company (situation). Motivation is a condition or energy that drives employee self-directed or directed to achieve organizational goals of the company. Mental attitude of employees are the pros and positil to strengthen the work situation is what his motivation to achieve maximum performance ".

Moh.UzerUsman (2000) motivation is "A process to encourage motives into action / behavior for meet, needs and achieve a state of readiness within the individual and which encourages the behavior to do something in achieving its objectives".

Based on the above understanding, the motivation can be defined as a state of mental and human mental attitude that energize, galvanize action (moves), and distribute leads or behavior towards reaching requirements give satisfaction or reduce dissatisfaction. Furthermore, based on this view, the motivation can be formulated as follows:

1) Every feeling, or will and desire that greatly affect the willingness of individuals so that the individual is encouraged to behave and act.

2) The influence of power that raises an individual's behavior.

3) Any action or event that causes changes in a person's behavior.

4) The process of determining the movement or behavior of individuals to the destination (goal).

The formulation of the above neutral, meaning that the formula does not specify the behavior-whether desirable or undesirable from the point of view. Therefore, from the above definition can be applied to the same problem and the cooperation of perseverance. On the other hand, these formulations are objective because the criterion is the action that occurs or does not occur.

\section{Elements Motivation}

In general, a form of motivation that is often adopted by the company include four elements, namely:

1) Compensation in the form of money. Compensation given to workers generally tangible money. Compensation as power for member motivation has always had a reputation for good name and indeed rightly so.

2) Directing and controlling. Direction is decisive for workers about what they should be doing and what they should not do. While the control is intended to determine that labor should be doing things that are instructed.

3) Determination of an effective working pattern. In general, the reaction to the boredom of work raises output inhibiting means for labor productivity.

4) Virtue. Virtue can be defined as an action taken deliberately by the management to influence attitudes or feelings of the workforce. In other words, virtue is an attempt to make workers happy.

\section{Company performance}

Company as one form of organization generally has a specific goal to be achieved in efforts to meet the interests of its members. Success in achieving the company's goal is the achievement of management. Assessment of achievement or performance of a company is measured because it can be used as a basis for decision making both internal and external parties. A company's performance is a picture of the financial condition of a company which is analyzed with the tools of financial analysis, so it can be known about the merits of a company's financial situation which reflects the performance in a particular period. It is very important that resources are used optimally in the face of environmental change.

Financial performance assessment is one way that can be done by the management in order to meet its obligations to funders and also to achieve the goals set by the company. Before understanding the performance appraisal problems more away, then there is some sense of performance as described by Helfert (1996: 67) that "The company's performance is the result of many individual decisions are made constantly by the management."

From these opinions can be seen that the performance is an indicator of good or poor management decisions in decisionmaking. Management can interact with internal and external environment through information. The information was further stated or summarized in the company's financial statements. Another understanding of the performance of "Performance is a measure of how efficiently and effectively an organization or a manager to achieve an adequate".

From the above it can be concluded that the performance (Performance.) Company is the result of many decisions are made constantly by the management to achieve certain goals effectively and efficiently.

\section{How to Improve Corporate Performance}

Creating an atmosphere conducive to work was not easy, climatic conditions and a healthy work activity is very effective in improving the performance of the company. To achieve that, not infrequently a company creating policies 
aimed at maximizing the potential of Human Resources (HR) has. As bonus reward, directly or indirectly, commissions, and various other examples.

To strengthen the management of Human Resources (HR) of a company depends on the pattern and the atmosphere working climate in a company. Policy manager (boss) is very influential on improving the performance of employees (subordinate), work climate activity can be created, and all come down to how healthy the creation of a direct interaction between superiors and subordinates.

There are several important points that perlu we remember in order to create a conducive working atmosphere. Below are 5 basic keys to boost the performance of:

\section{The specificity}

Employees require specification. Specification the complete information of the manner of execution was good and very helpful directional stability performance, while improving shortcomings. This can be achieved by the management Job Description (division of labor, duties and functions, authority, etc.) is good. This point can also be realized by placing the right person in the position / positions that suit their expertise (right man in the right job).

\section{Consistency}

Information should not be contradictory. For example, the regular assessment of good, but the annual appraisal bad. Inconsistencies like this can be unsettling and disturbing performance. At this point the system of monitoring and evaluation company must have a direction of achievement / performance standards and targets. It will be easier for companies to see the development progress and report data accurately. So it can be a reference in decision-making and good policy.

\section{Right time}

Feedback should be given immediately, so that employees are motivated to improve. If there is a reluctance to evaluate over time. They already feel right and would be devastated if it can be bad report card grades.

\section{Effective Communication}

Managers must be able to create effective communication to foster a shared understanding with the employees. Effective communication is very vital role in the creation of a healthy work atmosphere. Instructions are clear and correct boss should be understood by employees. At the moment there is a problem, should immediately resolved. If there are elements of both vertical conflict (manager-employee) or horizontally (fellow employees) in a company allowed to go on, it has the potential to destabilize the work climate.

\section{Framework Analysis}

From the picture below analytical framework can be explained that the relationship between independent variables $(\mathrm{X} 1, \mathrm{X} 2, \mathrm{X} 3)$ and the dependent variable $(\mathrm{Y})$. High and low performance $(\mathrm{Y})$ variables influenced Hard Skill (X1), Soft Skill (X2) and motivation (X3).

\section{Hypothesis}

In accordance with the description of the analytical framework discussed earlier, the research hypothesis can be

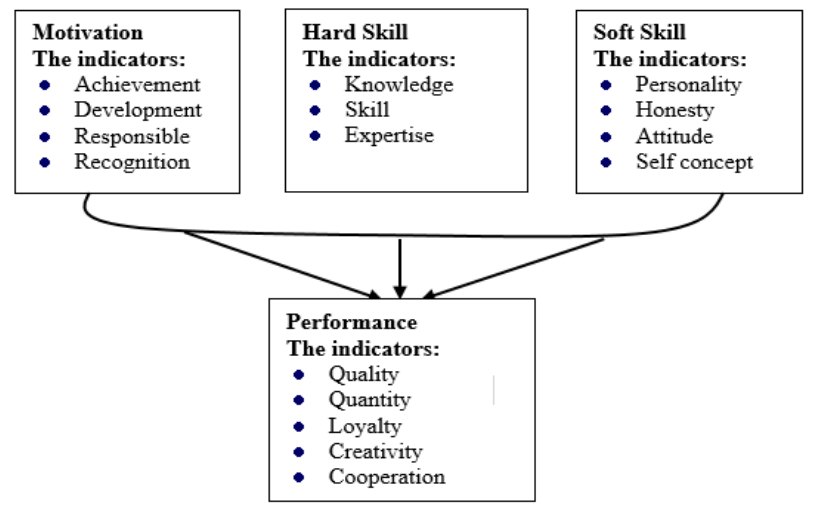

Figure 1 Framework Analysis

formulated as follows: There is a positive relationship between Hard Skills, Soft Skills and Motivation either partially or simultaneously Performance at PT. Manunggal Perkasa, meaning that if Hard Skills, Soft Skills and Motivation simultaneously increases, the performance at PT. Manunggal Perkasa will increase.

\section{RESEARCH METODE}

The method of analysis of this research is quantitative method, this research is the analysis unit employees working in PT. Manunggal Perkasa, employees 160 people study population and sample its investors with formula slovin with sample number 62 respondents. Research instrument is questionnaire analysis tool with multiple linear regression, the equation $\mathrm{Y}=\mathrm{a}+\mathrm{b} 1 . \mathrm{X} 1+\mathrm{b} 2 . \mathrm{X} 2+\mathrm{b} 3 . \mathrm{X} 3+\mathrm{e}$, where $\mathrm{Y}$ is $\mathrm{a}$ variable performance, $b 1, b 2$ and $b 3$ coefficients of variable coefficient variable X1, X2 and X3 (Soft Skill, Soft Skilld and Motivation) tool data analysis application program SPSS version 20.0.

Having analyzed using multiple linear regression, followed by a test of determination analysis ( $\mathrm{R}$ square), testing the hypothesis partially ( $\mathrm{t}$ test) and simultaneous (test $\mathrm{F}$ ) the error tolerance level of 5 percent. Before the process of multiple linear regression test in advance in research instruments (questionnaire) to test the validity and reliability as well as classical assumptions.

\section{RESULTS AND DISCUSSION \\ Research Object Description}

PT. Manunggal Perkasa is a service business engaged in the purchase of foreign online stores such as eBay, Amazon, Aliexpress, DHgate, etc. Or want to buy something from abroad? want to make a payment using PayPal, VISA? Or want to buy goods from the United States but the seller is not able to send to Indonesia.

Indoshopaholics.com a service business engaged in purchasing goods from foreign online stores such as eBay, Amazon, Aliexpress, DHgate, etc. Indoshopaholics.com has been operating since July 2011 and to date have been making purchases using Paypal, Visa, Mastercard, Gwallet of thousands Customers who give trust. Indoshopaholics can help you import needs both units as well as wholesale.

Indoshopaholics provide money back guarantee if the goods are not up. Depending on the type of service used. If using a standard service, we act as an intermediary for a buyer and a 
seller, buyer to use our services because they can not transact with sellers. Purchases will directly use the buyer's name and address sent to the buyer, so the responsibility is entirely in the hands of the buyer.

If using premium services, indoshopaholics act on behalf of buyers, so Indoshopaholics not an intermediary but positioned itself as a buyer. Purchases will use the name and sent to the address Indoshopaholics, so the responsibility is entirely in us. Premium service users do not need to bother because Indoshopaholics who will take care of everything door to door a money back guarantee.

\section{Descriptive analysis}

Analysis Skill Hard, Soft Skills, Motivation on the Performance of an analysis of the data derived from yamg questionnaire distributed to employees who work PT. Manunggal Perkasa. This study was conducted to determine the effect of Hard Skills, Soft Skills, motivation on performance.

In this study, respondents' answers measurements done using the Likert Scale and Grouping Table 3.1 Likert Scale in Table 3.2 to give a score to each of the answers to questions in the questionnaire. From the questions on the questionnaire that has been submitted to the respondent obtained a wide range of responses to variable Skill Hard, Soft Skills, motivation on performance. Various respondents are summarized and presented below.

\section{Hard Skill}

Table 1 Distribution Score Answers Question Variable Hard Skill

\begin{tabular}{|c|c|c|}
\hline \multirow[b]{2}{*}{ Answer } & \multicolumn{2}{|c|}{ Score Answer } \\
\hline & Total & Percentage (\%) \\
\hline Very Agree (5) & 248 & $33,3 \%$ \\
\hline Agree (4) & 301 & $40,5 \%$ \\
\hline Doubtful (3) & 177 & $23,8 \%$ \\
\hline Disagree(2) & 18 & $2,4 \%$ \\
\hline Very Disagree (1) & 0 & 0 \\
\hline Total & 744 & $100 \%$ \\
\hline
\end{tabular}

Variable Hard skill (X1) were measured using 12 pieces of questions. Pensekoran done by using a Likert scale of 1-5, the entire score of the answers collected for the variables are as many as 744 Hard Skill statement, which comes from the 62 respondents with a total of 12 questions. Referring to the distribution of scores in the table can be seen that as many as $33.3 \%$ of the respondents strongly agree agree, $40.5 \%$ agree, $23.8 \%$ undecided, and $2.4 \%$ did not agree. Of the total respondents answered variables Hard skill most agree with the presentation of as much as $40.5 \%$.

\section{Soft Skill}

Table 2 Distribution Score Answers Question Variable Soft Skills

\begin{tabular}{|c|c|c|}
\hline \multirow[b]{2}{*}{ Answer } & \multicolumn{2}{|c|}{ Score Answer } \\
\hline & Total & Percentage (\%) \\
\hline Very Agree (5) & 200 & $46,1 \%$ \\
\hline Agree (4) & 166 & $38,2 \%$ \\
\hline Doubtful (3) & 52 & $12 \%$ \\
\hline Disagree(2) & 16 & $3,7 \%$ \\
\hline Very Disagree(1) & 0 & $0 \%$ \\
\hline Total & 434 & $100 \%$ \\
\hline
\end{tabular}

Softskill variable (X2) were measured using seven pieces of questions. Scoringdone by using a Likert scale of 1- 5 . The entire score of the answers collected for the variables are as many as 434 Hard Skill statement from the 62 respondents with a total of 7 questions.

Referring to the distribution of scores in the table can be seen that as many as $46.1 \%$ of the respondents strongly agree agree, $38.2 \%$ agree, $12 \%$ undecided, and $3.7 \%$ did not agree. Of the total respondents answered variables Soft Skill most strongly agree with the presentation of as much as $46.1 \%$.

\section{Motivation}

Table 3 Score Distribution Variable Answers Questions Motivation

\begin{tabular}{|c|c|c|}
\hline \multirow[b]{2}{*}{ Answer } & \multicolumn{2}{|c|}{ Score Answer } \\
\hline & Total & Percentage (\%) \\
\hline Very Agree (5) & 329 & $40,8 \%$ \\
\hline Agree (4) & 340 & $42,2 \%$ \\
\hline Doubtful (3) & 114 & $14,1 \%$ \\
\hline Disagree (2) & 23 & $2,9 \%$ \\
\hline Very Disagree (1) & 0 & $0 \%$ \\
\hline Total & 806 & $100 \%$ \\
\hline
\end{tabular}

Motivation variable (X3) were measured using 13 pieces of questions. Scoring done by using a Likert scale of 1-5 the entire score of the answers collected for motivation variable is 806 statements, which comes from the 62 respondents with a number of 13 questions.

Referring to distribution score in the table can be seen that as many as $40.8 \%$ of the respondents strongly agreed, $42.2 \%$ agree, $14.1 \%$ undecided, and $2.9 \%$ did not agree. Of the total respondents answered most motivational variables agree with the presentation of as much as $42.2 \%$.

\section{Performance}

Table 4 Variable distribution Performance Score Answers Questions

\begin{tabular}{|l|c|c|}
\hline \multirow{2}{*}{ Answer } & \multicolumn{2}{|c|}{ Score Answers } \\
\cline { 2 - 3 } & Total & Percentage (\%) \\
\hline Strongly Agree (5) & 175 & $35,3 \%$ \\
\hline Agree (4) & 237 & $47,8 \%$ \\
\hline Hesitate (3) & 84 & $16,9 \%$ \\
\hline Disagree (2) & 0 & $0 \%$ \\
\hline Strongly Disagree (1) & 0 & $0 \%$ \\
\hline Total Source: Data compiled from the survey \\
\hline \multicolumn{2}{|c|}{} \\
\hline
\end{tabular}

Performance variables (Y) was measured using eight pieces of questions. scoring done by using a scale of 1- 5 Liken all scores answers collected for the performance variables are as many as 496 statements, which comes from the 62 respondents to the number of 8 questions.

Referring to the distribution of scores in the table can be seen that as many as $35.3 \%$ of the respondents strongly agreed, $47.8 \%$ agree, $16.9 \%$ undecided. The total respondents answered most motivational variables agree with the presentation of as much as $42.2 \%$.

\section{The effect of partially ( $t$ test)}

$\mathrm{T}$ test (partial regression test) is used to determine whether partial Hard Skills, Soft Skills, Motivation gives significant positive effect partially on performance. Tests using a 
significant level of 0.05 and 2 sides.

Hypothesis test between Hard Skills, Soft Skills, Motivation affect the performance can be used to search for the $t$ test statistic by comparing $\mathrm{t}$ test with $\mathrm{t}_{\text {table. }}$

- If $\mathrm{t}_{\text {count }}<\mathrm{t}_{\text {table, }}$ then Ho is accepted

- If $\mathrm{t}_{\text {count }}>\mathrm{t}_{\text {table, }}$, then Ho is rejected

Coefficients $\mathrm{t}$ test analysis with SPSS processing, the data obtained as follows:

Table 5. Coefficients

Coefficients $^{\mathrm{a}}$

\begin{tabular}{|c|c|c|c|c|c|}
\hline \multirow{2}{*}{ Model } & \multicolumn{2}{|c|}{$\begin{array}{c}\text { Unstandardized } \\
\text { Coeffecients }\end{array}$} & $\begin{array}{c}\text { Standardized } \\
\text { Coeffecients }\end{array}$ & \multirow{2}{*}{ t } & \multirow{2}{*}{ Sig. } \\
\cline { 2 - 5 } & $\mathrm{B}$ & $\begin{array}{c}\text { Std. } \\
\text { Error }\end{array}$ & Beta & & \\
\hline 1 (Consatant) & 6.842 & 3.365 &. & 2.033 & 0.047 \\
\hline Hard Skill & 0.152 & 0.058 & 0.262 & 2.622 & 0.011 \\
\hline Soft Skill & 0.264 & 0.113 & 0.262 & 2.329 & 0.023 \\
\hline Motivation & 0.208 & 0.065 & 0.382 & 3.213 & 0.002 \\
\hline
\end{tabular}

a Dependent Variable: Performance

Source: Results of data processed SPSS

\section{CoefficientVariableHard Skill Testing}

From table 5 can be explained that the $\mathrm{t}_{\text {value }}$ is 2.622 and 0.011 significant, after $\mathrm{t}_{\text {count }}$ it must find the value of $\mathrm{t}_{\text {table }}(\alpha=0.05)$ was 1.99. Because $t_{\text {value }}>t$ table is $(2.622>1.99)$ with a significance level $<0.05(0.011<0.05)$, then Ho is rejected, the conclusion that the Hard Skill partially positive effect on performance.

\section{CoefficientVariable Soft Skill Testing}

And table 5 can be explained that $\mathrm{t}$ count is 2,329 and 0,023 significant after $\mathrm{t}_{\text {value }}$ it must find $\mathrm{t}_{\text {table }}(\alpha=0.05)$ was 1.99 . Because the $t_{\text {value }}>t$ table is $(2,329>1,99)$ with a significance level $<0.05(0.002<0.05)$, then Ho is rejected, the conclusion that the partial Soft Skill significant and positive impact on performance.

\section{CoefficientVariable MotivationTesting}

And table 5 can be explained that a significant $t_{\text {count }}$ is 3,213 and 0,002 , after $t_{\text {count }}$ it must find $t_{\text {tabel }}(a=0.05)$ was 1.99 . Because the $t_{\text {value }}>t t_{\text {able }}$ is $(3,213>1,99)$ with a significance level of $0.05(0.004<0.05)$, then $\mathrm{Ho}$ is rejected, the conclusion that the motivation is partially significant effect on performance.

\section{Simultaneous influence (Test F)}

F-test was used to test significant regression coefficients along namely whether the independent variables have an influence on the dependent variable. In this case the role of the ANOVA is to test the significance of the influence of Hard Skills, Soft Skills, Motivation together on Performance.

Hypothesis test between Hard Skill, So Skill, Motivation on Performance can be used to search for the F test statistic by comparing test $\mathrm{F}$ with $\mathrm{F}$ table.

If $\mathrm{F}_{\text {count }}<\mathrm{F}$ table, then Hard Skills, Soft Skills, Motivation in Simultaneous no effect on performance.
$>$ If the $\mathrm{F}_{\text {count }}>\mathrm{F}_{\text {table, }}$, then Hard Skills, Soft Skills, Motivation in simultaneous effect on performance.

F test using Anova analysis with SPSS rocessing, the data obtained as follows:

Table 6.Anova

\begin{tabular}{|c|c|c|c|c|c|}
\hline \multicolumn{6}{|c|}{ ANOVA $^{b}$} \\
\hline Model & $\begin{array}{c}\text { Sum of } \\
\text { Squares }\end{array}$ & df & $\begin{array}{c}\text { Mean } \\
\text { Square }\end{array}$ & $\mathbf{F}$ & Sig. \\
\hline Regression & 483.524 & 3 & 161.175 & 21.744 & $.000^{\mathrm{a}}$ \\
\hline Residual & 429.912 & 58 & 7.412 & & \\
\hline Total & 913.435 & 61 & & & \\
\hline
\end{tabular}

From table 6 can be explained that the value $F_{\text {count }} 21.744$ with a significant level of 0.000 . Once the value of $F$ it must find $F_{\text {table }}$ value $(\alpha=0.05)$ was 2.76 . Because the value of $F$ is greater than $\mathrm{F}$ table $(21.744>2.76)$ with a significant level of $0.000<0.05$, it can be concluded that Ho is rejected, meaning Hard Skills, Soft Skills, Motivation simultaneously affect the performance.

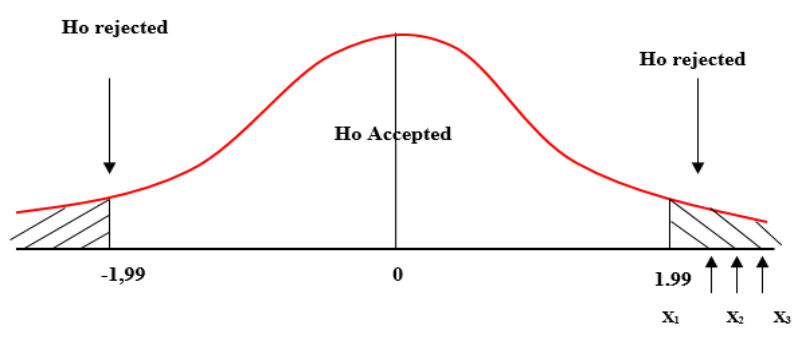

Figure 2 Effect of Hard Skills, Soft Skills and Motivation Influential Significant performance against

\section{Discussion}

Based on the results of multiple linear regression analysis using SPSS 15 obtained results: $\mathrm{Y}=6.842+0,152 \mathrm{X} \_1+$ 0,264X_2+0,208X_3, as follows:

(a) Based on the formula of the model has implications for the regression equation can be explained as follows value in variabe 1 constant of 6.842 states if no Hard Skills, Soft Skills, Motivation (X1, X2, $\mathrm{X} 3,=0$ ), then the performance is in position positive 6.842 .

(b) Based on the value of the correlation coefficient of 0.728. This shows a strong relationship between the Hard Skills, Soft Skills, motivation on performance. Adjusted R Square called the coefficient of determination. Based on the above table obtained figures Adjusted R2 (R square) of 0.505 or $50.5 \%$. This shows that the $50.5 \%$ performance is influenced by Hard Skills, Soft Skills, motivation. While the remaining $49.5 \%$ is influenced by other factors not examined.

(c) Based on the partial correlation coefficient 9.503 $\mathrm{X} 1$ and $\mathrm{Y}$ of these results can be interpreted that the variable $\mathrm{X} 1$ and $\mathrm{Y}$ partially have a positive relationship in a significant level moderate. From the above table unknown partial correlation coefficient between $\mathrm{X} 2$ and $\mathrm{Y}$ of 0.570 this can be interpreted that between $\mathrm{X} 2$ and $\mathrm{Y}$ partially have a positive relationship in a significant level moderate. Partial correlation coefficient between the X3 and $\mathrm{Y}$ of 0.650 this can be interpreted that between $\mathrm{X} 3$ 
and $\mathrm{Y}$ partially have a positive relationship in the relatively strong significant level. And it can be concluded that the greatest effect is the effect of motivation on performance.

(d) The value of $F$ of 21.744 with a significant level of 0.000 after the value of $F$ it must find $F_{\text {table }}$ value $(\alpha$ $=0.05)$ was 2.76. Because the value of $F$ is greater than $F_{\text {table }}(21.744>2.76)$ with a significant level of $0.000<0.05$, it can be concluded that Ho is rejected, meaning Hard Skills, Soft Skills, Motivation jointly affect the performance.

(e) $\mathrm{T}$ test results obtained:

- For Variable Hard Skill $t_{\text {count }}$ significant at 2.622 and 0.011 after $\mathrm{t}_{\text {count }}$ it must find the value of $\mathrm{t}_{\text {table }}(\alpha=0.05)$ was 1.99 . Because the value of $t>t$ table ie $(2.622>1.99)$ with a significance level $<0.05(0.000<0.05)$, then Ho is rejected, the conclusion that the Hard Skill partially significant effect on performance.

- For Variable Soft Skill significant $t_{\text {count }} 2,329$ and 0,023 , after $t$ value it must find $t_{\text {table }}(\alpha=0.05)$ was 1.99. Because the value of $t>t$ table ie $(2,329>1,99)$ with a significance level $<0.050 .023<0.05$ ), then Ho is rejected, the conclusion that the Soft Skill partially significant effect on performance.

- For variable Motivation significant $t_{\text {count } 3,213}$ and 0,002 , after $\mathrm{t}_{\text {count }}$ it must find $\mathrm{t}_{\text {table }}(\alpha=0.05)$ was 1.99 . Because the value of $\mathrm{t}>\mathrm{t}$ table $\mathrm{ie}(3,213>1,99)$ with a significance level $<0.05(0.004<0.05)$, then $\mathrm{Ho}$ is rejected, the conclusion that the motivation is partially significant effect on performance.

\section{CONCLUSIONS}

From the results of this study can be summarized as follows:

1. From the multiple linear regression equation is as follows mind that, if the Hard Skill (X1) have increased, there will be an increase in performance $(\mathrm{Y})$, if the Soft Skill (X2) have increased, there will be an increase in performance $(\mathrm{Y})$, and motivation (X3) increase will be an increase in performance $(\mathrm{Y})$.

2. From the results of correlation analysis showed a strong association between Hard Skill (X1), Soft Skill (X2) and motivation (X3) on the performance at PT. Manunggal Perkasa (Y).

3. Based on the coefficient of determination or adjusted $\mathrm{R}$ Square contribution to performance (Y) of 0.505 or $50.5 \%$ and the remainder caused by other factors not examined.

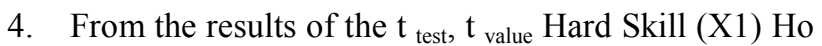
is rejected it can be concluded that the factors Hard Skill (X1) has a real and significant effect on company performance in PT. Manunggal Perkasa (Y).

5. From the results of the $t_{\text {test }}, t$ value Soft Skill (X2) Ho is rejected it can be concluded that the factor Soft Skill (X2) has a real effect and no significant effect on the performance of the PT. Manunggal Perkasa.

6. And the results of the $t_{\text {test }}, t$ value Motivation (X3) Ho is rejected it can be concluded that the factor of motivation (X3) has a real effect and no significant effect on the company's performance.

7. From the test results F, Ho refused meaning Hard Skill (X1), Soft Skill (X2), and motivation (X3) simultaneously affect the performance of PT. Manunggal Perkasa. Results validity and reliability can be seen in the output SPSS 17.0 in items about statistics and reability statistics, point declaration to test the validity and reliability consists of 12 statements about Hard Skill (X1), 7 statement regarding Soft Skills (X2), 13 statements about motivation and 8 statements regarding performance (Y). Declared invalid if the results obtained greater $r_{\text {count }} r_{\text {table }}$, for $\mathrm{N}=62$ is obtained $r$ table 0,361 , and otherwise reliable if the Cronbach alpha value is greater than 0.7. Of all the statements in the questionnaire used in this study is valid and reliable, then it can be used to measure what is to be measured.

\section{RECOMMENDATION}

Based on the overall results of this study, the authors try to put forward some suggestions that would be useful for Soft Skill Improvement and Motivation to company performance Manunggal Perkasa, are as follows:

1. Hard Skill, Soft Skill and Motivation affect the Company's performance Manunggal Perkasa which shows a very good level of qualification. This needs to be maintained and improved to Hard Skill, Soft Skill, motivation to improve enterprise performance and can run well.

2. In applying the company's performance should see which employees have a high motivation, Soft Skill can be placed on the field ruled. With the Hard Skills, Soft Skills, Motivation is expected to improve morale in the work.

3. To further improve the performance of the company, efforts were made not only through the provision of motivation but can be other shapes by creating a harmonious working atmosphere.

\section{REFERENCE}

Dessler. Gary 2003. Human Resource Management Jakarta: Prenhallindo.

Fitt-ens, Jack and Barbara Davison. 2009. Nora to Measure Human Resources Management Prenada Media Group. Jakarta.

Handoko, H., 2000. The duo Somber Personnel Management Human Resources. Yogyakarta: Yogyakarta BPFE.

Hasibuan. Malay S.P. 2009. Human Resource Management. PT. Earth Literacy. Jakarta.

Mangkunagara: A. P. 2005. Human Resource Management Company. Bandung: PT. Teens Rosadakarya.

Mundy, Wayne. Dya 2000 Human Resource Management. Tenth edition, vol 2. Jakarta: Erland.

Nawawi, H. 2002. Human Resource Management for Competitive Business Yogyakarta: Gadjah Mada University Press.

US Nitisentimo. $2001 \&$ 2007. Personnel Management (Human Resource Management) Jakarta: Ghalia.

Ramdhani, N.(2008). Attitude and a few definitions to unders tand it. On line]. Available:http://neila.staffugm.ae id/wor dpress/wpcontent/uploads/2008/03/definisi.pdf.

Sedarmayanti.2001 \& 2007. Human Resources and Labor Productivity: Bandung Ilham Jaya. 
Sugiyono. (2005) Understanding Quantitative Research, Ban d ung alphabet.

James.A.F. (2006). Management, Volume I. Issue Four Sale$\mathrm{m}$ ba, Jakarta.

\section{Please cite this article in press as:}

Gimbal Doloksaribu (2017), Company performance: analysis of hardskill, soft skill and motivation at the PT. Manunggal Perkasa , International Journal of Current Advanced Research, 6 (03), pp. 2996-3004.

http://dx.doi.org/10.24327/ijcar.2017.3004.0163.

H.M.2013. Human Resource Management. Jakarta: Partners Media Discourse.

\footnotetext{
$* * * * * * *$
} 